\title{
Stimulatory effect of $17 \beta$-estradiol on osteogenic differentiation potential of rat adipose tissue-derived stem cells
}

\author{
Dilek Taskiran and Vedat Evren \\ Department of Physiology, Ege University School of Medicine, 35100 Izmir, Turkey
}

\begin{abstract}
Adipose tissue-derived stem cells (ADSCs) are considered as a potential cell source for regenerative medicine and tissue engineering. Although ADSCs have greater proliferation capacity than bone marrow stem cells (BMSCs), lower differentiation ability of these cells limits their utility in experimental and clinical studies. The purpose of this study was to investigate whether $17 \beta$-estradiol $\left(\mathrm{E}_{2}\right)$ has a stimulatory effect on osteogenic differentiation potential of ADSCs in vitro. ADSCs were isolated from visceral adipose tissues of rats and treated with different concentrations of $E_{2}$ in osteogenic medium $(\mathrm{OM})$ for 21 days. The differences in osteogenic differentiation potential of the cultures were assessed by von Kossa staining, measurement of alkaline phosphatase (ALP) activity and calcium levels. ADSCs cultured in $\mathrm{OM}$ supplemented with $\mathrm{E}_{2}$ showed greater bone-like nodule formation and mineral deposition in comparing with the cells grown in OM. In addition, ALP activity and calcium levels also were significantly higher in the cultures exposed to $\mathrm{E}_{2}$ than the cells treated only with $\mathrm{OM}(p<0.005, n=5)$. Our results suggest that $\mathrm{E}_{2}$ may stimulate the osteogenic differentiation of ADSCs and therefore, can be used as an inducing agent to improve the efficiency of these cells in in vitro and in vivo studies.
\end{abstract}

Key words: Adipose tissue - Stem cell - Osteogenesis - Rat - Estradiol - Differentiation

\begin{abstract}
Abbreviations: AA, ascorbic acid; $\mathrm{ADSC}_{S}$, adipose-tissue derived stem cells; ALP, alkaline phosphatase; $\beta$ GP, $\beta$-glycerophosphate; BMSCs, bone marrow stem cells; Dex, dexamethasone; DMEM, Dulbecco's Modified Eagle medium; $\mathrm{E}_{2}, 17 \beta$-estradiol; FBS, fetal bovine serum; OM, osteogenic medium PBS, phosphate-buffered saline.
\end{abstract}

\section{Introduction}

Recently, stem cells have been recognized as an attractive source for regenerative medicine and tissue engineering. Although embryonic stem cells have enormous self-renewal capacity and multilineage potential, their use in experimental and clinical studies are limited due to many ethical and political issues. Therefore, adult stem cells from stromal compartment of mesenchymal tissues have been proposed as an alternative source for cell-based therapies (Alhadlaq and Mao 2004; Krampera et al. 2006; Caplan 2007). To date, stromal cells or often called mesenchymal stem cells have been isolated from bone marrow, muscles, skin and adipose tissue and characterized widely (Krampera et al. 2006; Caplan 2007;

Correspondence to: Dilek Taskiran, Department of Physiology, Ege University School of Medicine, Bornova-Izmir, Turkey

E-mail: dilek.taskiran@ege.edu.tr
Peng et al. 2008). Mesenchymal stem cells include three major characteristics: the ability to adhere to plastic surfaces to form fibroblastic colonies, extensive proliferative capacity and the ability to differentiate into several cell lineages.

Bone marrow is the main reserve of the stem cells and contains two types of stem cell populations: hematopoetic stem cells and mesenchymal stem cells. Although mesenchymal stem cells represent a very small portion of the nucleated cells in marrow they can be isolated and expanded with high efficiency under well-defined culture conditions. Previous studies have reported that bone marrow stem cells (BMSCs) can selectively form osteoblasts, chondrocytes, adipocytes in vitro in response to appropriate growth media (De Ugarte et al. 2003; Romanov et al. 2005; Peng et al. 2008). Adipose tissue is also derived from mesenchyme, and adipose tissuederived stem cells (ADSCs) can proliferate extensively and give rise to several lineages such as osteoblasts, adipocytes and chondrocytes similar to BMSCs (Zuk et al. 2002; De 
Ugarte et al. 2003; Romanov et al. 2005; Peng et al. 2008). Compare with bone marrow, adipose tissue is a practical and alternative mesenchymal stem cell source for stem cell and regenerative medicine studies due to the simplicity of extracting cells in a large volume with minimal morbidity. Although differentiation capacity of ADSCs is generally lower than BMSCs, recent evidences suggest that effective modulation of ADSCs in vitro may improve their proliferation and differentiation potential (Zhu et al. 2008).

Bone formation is a complex process including proliferation of osteoprogenitor cells and the differentiation of pre-osteoblasts into mature osteoblasts which produce and mineralize bone matrix during pre- and postnatal life. Several hormones and local factors are essential to stimulate osteogenic differentiation in vitro and in vivo. Adult stem cells typically require dexamethasone (Dex), ascorbic acid (AA) and $\beta$-glycerophosphate $(\beta \mathrm{GP})$ to differentiate into osteoblasts and produce a mineralized matrix in vitro. Recent studies mention a positive effect of Dex on in vitro bone nodule formation and mineralization, whereas $\beta \mathrm{GP}$ is generally used as a source of organic phosphate for the formation of hydroxyapatite in culture systems (Jaiswal et al. 1997; Huang et al. 2002).

It is well recognized that estrogen has modulatory effects on cell growth and differentiation via its intracellular receptors and stimulation-related genes (Zhou et al. 2001; Hong et al. 2004; Ray et al. 2008). Recent studies have demonstrated the presence of estrogen receptors on embryonic stem cells, supporting that estrogen may alter the functions of those cells (Hong et al. 2004; Han et al. 2006). In a previous study, 17 $\beta$ estradiol $\left(E_{2}\right)$ has been reported to enhance the expression of genes for alkaline phosphatase (ALP) activity, collagen I and TGF- $\beta 1$ by mesenchymal stem cells in osteoporotic mice (Zhou et al. 2001). Although data are reported regarding the role of estrogens on osteogenic differentiation of BMSCs both in animals and human, there is limited information about the effect of estrogens on osteogenic potential of ADSCs. The purpose of this study was to investigate whether $\mathrm{E}_{2}$ treatment has a stimulatory effect on osteogenic differentiation potential of ADSCs isolated from rats. For this reason, we exposed rat ADSCs to different concentrations of $\mathrm{E}_{2}$ in the culture medium and measured osteogenic capacity of these cells with histological and biochemical methods.

\section{Materials and Methods}

\section{Isolation of ADSCs}

Eight adult Sprague-Dawley rats weighing approximately 200-250 g were used in the study. The protocols employed in the study were approved by the Institutional Animal Ethics Committee of Ege University, Izmir. All chemicals and culture media were obtained from Sigma Chemicals. Rats were euthanized with an overdose of sodium pentobarbital before the experiments. ADSCs were isolated from the visceral adipose tissue of the rats. Briefly, a midline incision was made in the epigastric area of the rat and abdominal cavity and its contents were exposed. Visceral adipose tissues around the stomach, intestines and bilateral inguinal region were carefully dissected away from the body and put in ice-cold sterile phosphate-buffered saline solution (PBS) (Huang et al. 2002; Tholpady et al. 2003). The adipose tissue was rinsed three times with PBS, finely minced with scissors and then digested with $0.075 \%$ collagenase I with vigorous shaking at $37^{\circ} \mathrm{C}$ for 1 hour. After the collagenase I was neutralized by adding equal volume of Dulbecco's Modified Eagle medium (DMEM), the cells were filtered by using a cell strainer to remove the debris, rinsed twice with DMEM with $10 \%$ fetal bovine serum (FBS) and $1 \%$ antibiotic/antimycotic and centrifuged at $500 \times g$ for 5 minutes. Finally, the cells were re-suspended in $1 \mathrm{ml}$ of serum-containing medium and cell count and cell viability were determined by trypan blue staining. The nucleated cells ( 2.5 $\times 10^{5}$ ) were plated in $100 \mathrm{~mm}$ dishes in medium consisting of DMEM with $10 \%$ FBS and $1 \%$ antibiotic/antimycotic. The cells were incubated in an incubator at $37^{\circ} \mathrm{C}$ with $5 \% \mathrm{CO}_{2}$ and culture medium was refreshed every $2-3$ days. When the large fibroblast-like cell colonies developed and reached $80 \%$ confluence, cultures were harvested with $0.25 \%$ trypsin/EDTA for $5-10 \mathrm{~min}$ at $37^{\circ} \mathrm{C}$ and re-plated on $100 \mathrm{~mm}$ dish. The resulting cultures were referred to as first passage cultures. The primary and passage cultures were examined and photographed using a phase-contrast microscope. Passage 5 cells were used to evaluate both osteogenic and chondogenic potentiality.

\section{Osteogenic differentiation}

ADSCs at passage 5 were seeded on to 24 -well plates at a density $1 \times 10^{4} /$ well in DMEM supplemented with $10 \%$ FBS and $1 \%$ antibiotic/antimycotic. Medium was changed the day after seeding and then every 3 days. When the cells reached $70-80 \%$ confluency, cultures were treated with osteogenic medium (OM) consisting of $50 \mu \mathrm{M} \mathrm{AA}, 100 \mathrm{nM}$ Dex and 10 $\mathrm{mM} \beta \mathrm{GP}$ for 21 days in vitro (Jaiswal et al. 1997; Tholpady et al. 2003). In addition, to evaluate the effect of $\beta G P$ and Dex on osteogenic capacity of ADSCs, some of the cultures were incubated in different doses of Dex (10 and $1000 \mathrm{nM})$ and $\beta \mathrm{GP}$ (5 and $50 \mathrm{mM}$ ). To examine the effect of $\mathrm{E}_{2}$ on osteogenic potential of ADSCs, the cells were exposed to different concentrations of $\mathrm{E}_{2}\left(10^{-12}, 10^{-10}\right.$ and $\left.10^{-8} \mathrm{M}\right)$ in $\mathrm{OM}(50 \mu \mathrm{M}$ $\mathrm{AA}+100 \mathrm{nM}$ Dex $+10 \mathrm{mM} \beta$ GP in DMEM supplemented with $10 \% \mathrm{FBS}$ and $1 \%$ antibiotic/antimycotic). Control group was treated with only control medium containing DMEM supplemented with $10 \% \mathrm{FBS}$ and $1 \%$ antibiotic/antimycotic. The cells were cultured for 21 days and osteoblastic activity in the cultures was assessed by von Kossa staining, calcium and ALP activity measurement. 


\section{Chondrogenic differentiation}

To evaluate the multipotency of ADSCs, cells were also induced with chondrogenic medium using pellet culture system. For the preparation of each pellet, passage 5 cells were trypsinized, counted and resuspended in a chondrogenic basal media consisting of high glucose-DMEM supplemented by $10 \mathrm{ng} / \mathrm{ml}$ transforming growth factor- $-\beta 1,100 \mathrm{nM}$ Dex, 6.25 $\mu \mathrm{g} / \mathrm{ml}$ insulin transferin, selenium + premix (ITS), $50 \mu \mathrm{g} / \mathrm{ml}$ ascorbate-2-phosphate, $40 \mu \mathrm{g} / \mathrm{ml}$ proline, $100 \mu \mathrm{g} / \mathrm{ml}$ pyruvate and $1 \%$ antibiotic/antimycotic. Briefly, aliquots of $1 \times 10^{6}$ cells were spun down at $800 \times g$ in $15 \mathrm{ml}$ conical tubes and cultured at $37^{\circ} \mathrm{C}, 5 \% \mathrm{CO}_{2}$ for 21 days by changing the medium every 2-3 days. Finally, the pellets were collected and proteoglycan production in the extracellular matrix was visualized by toluidine blue staining (Shirasawa et al. 2006).

\section{von Kossa staining}

The secretion of calcified extracellular matrix was evaluated with von Kossa staining (Huang et al. 2002). The cells were rinsed with deionized water and fixed with $10 \%$ formalin solution for 30 minutes. After rinsing three times with deionized water, wells were incubated in $5 \%$ silver nitrate solution $(\mathrm{w} / \mathrm{v})$ for $1 \mathrm{~h}$ in the dark, rinsed with deionized water and exposed to UV light for 30 minutes. After adding 5\% sodium thiosulfate for the neutralization of residual silver nitrate, cells were rinsed with deionized water and dried for light microscopic examination. von Kossa positive deposits were visualized as dark brown or black precipitates.

\section{Total calcium assay}

Cell layers were rinsed with PBS and extracted with $1 \mathrm{ml}$ of $0.5 \mathrm{~N} \mathrm{HCl}$ for $1 \mathrm{~h}$ with continuous shaking at room temperature. After centrifugation at $1000 \times g$ for $5 \mathrm{~min}$, calcium levels in the supernatants were determined spectrophotometrically using $o$-cresolphthalein complexon method (Jäger et al. 2005). In this method, calcium forms a purple-colored complex with $o$-cresolphthalein complexon in alkaline AMP buffer. The intensity of the color was measured at $540 \mathrm{~nm}$ and compared with a standard solution.

\section{ALP activity assay}

The ALP activity was determined spectrophotometrically by measuring the release of $p$-nitrophenol from $p$-nitrophenyl phosphate as substrate (Jaiswal et al. 1997). Briefly, the cells were rinsed with distilled water and incubated with the substrate prepared in substrate buffer (50 mM glycine, $1 \mathrm{mM} \mathrm{MgCl}_{2}, \mathrm{pH}$ 10.5) for 15 minutes. After the reaction was stopped with $1 \mathrm{M} \mathrm{NaOH}$, the absorbance of the samples were read at $405 \mathrm{~nm}$ and compared with a $p$-nitrophenol standard solution. Enzyme activity was expressed as nmol of $p$-nitrophenol $/ \mu \mathrm{g}$ protein.

\section{Total protein assay}

Total protein concentration in the cell lysates was determined according to Bradford's method using bovine serum albumin as standard (Bradford 1976).

\section{Statistical analysis}

All quantitative data were analyzed by using non-parametric (Mann-Whitney U) test. Student's $t$-test was used to evaluate the differences between the groups. Data are presented as mean values \pm standard error of the mean (SEM). A two tailed $p$-value smaller than 0.05 was considered statistically significant.

\section{Results}

\section{Morphological evaluation of the cultures}

In the present study, rat ADSCs were used to assess the effects of estrogen on osteogenic differentiation. The morphology of the cells was evaluated daily during the primary and passage cultures. The initially adherent cells grew into spindle-shaped cells and colonies became visible around the $3^{\text {rd }}$ day of the cultures. Primary cultures were passaged when large colonies developed and reached $80 \%$ confluence (Fig. 1). The fibroblastlike morphology became more homogenous and confluent by days $7-8$ of the passage cultures. While the cultures in control

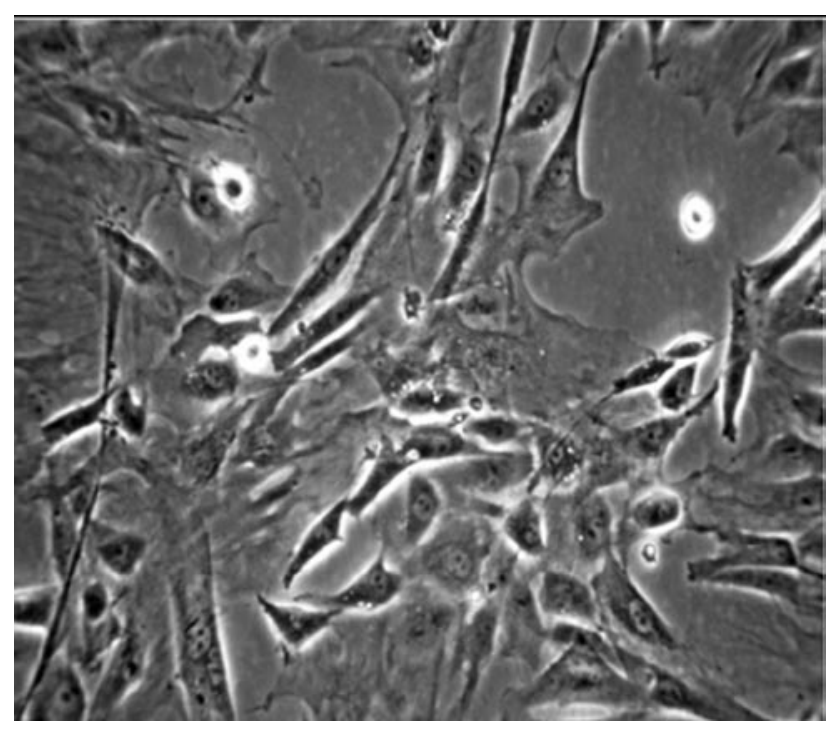

Figure 1. Morphology of rat ADSCs cultured in monolayer. The cells exhibited fibroblast-like shape. Original magnification $\times 40$. 


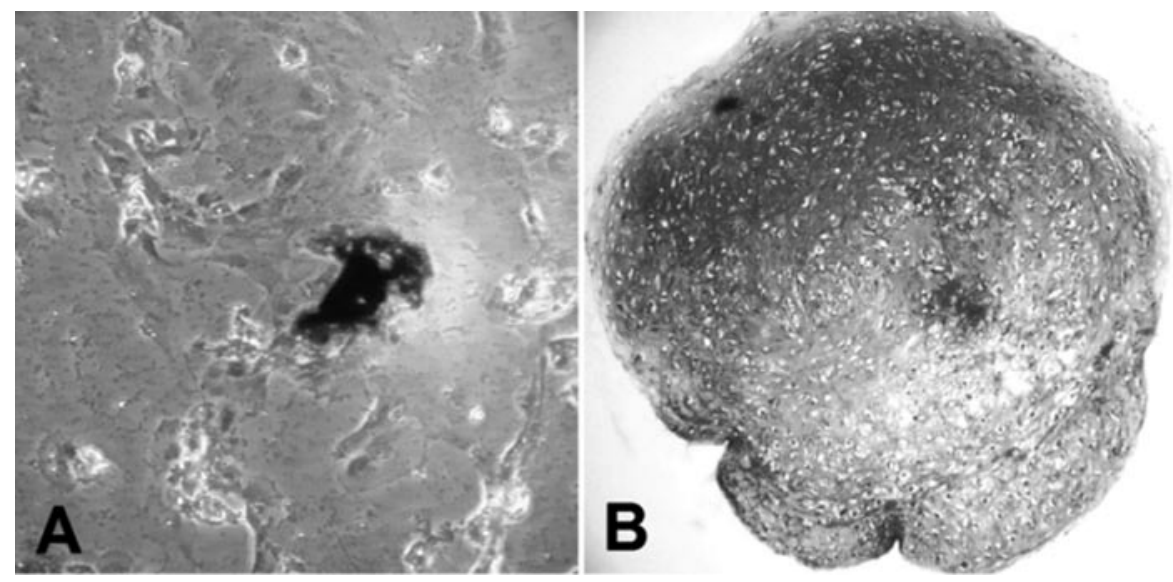

Figure 2. Osteogenic and chondrogenic differentiation of ADSCs. A. Cells placed in OM lost their characteristic shape and began to form cell aggregates. The mineralization of the bone-like nodules was observed as black deposits with von Kossa staining. B. Chondrogenic potential of ADSCs. Histological analysis of pellets by toluidine blue staining demonstrated proteoglycan synthesis in the matrix. Original magnification $\times 40$.

medium proliferate uniformly and demonstrate fibroblast-like morphology, ADSCs placed in OM (containing $50 \mu \mathrm{MAA}+100$ $\mathrm{nM}$ Dex $+10 \mathrm{mM} \beta \mathrm{GP}$ ) lost their characteristic shapes and became mostly polygonal or cuboidal. Typically, OM-induced cells began to form cell aggregates and bone-like nodules by day 8 of the cultures. Mineralization of the nodules was observed during the second week of the cultures (Fig. 2A) while control cultures never formed nodule and mineralization. To evaluate the chondrogenic potential of ADSCs, pellet cultures were prepared from Passage 5 cells and cultured in chondrogenic medium for 21 days. Histological evaluation of pellet cultures demonstrated proteoglycan synthesis in the matrix (Fig. 2B).

\section{Effect of $\beta G P$ and Dex on osteogenic differentiation}

The osteogenic potential of ADSCs was also studied by measuring ALP activity and calcium levels in cell lysates. Table 1 compares the effect of OM and different doses of $\beta$ GP and Dex on ALP activity and calcium content in the cultures. Statistical analysis of the data demonstrated significant differences between the groups for both ALP activity and calcium deposition measured in the cultures (ANOVA, $p<0.0005$ ). The incubation of ADSCs with OM for 21 days caused a significant increase in ALP activity and calcium levels compared with the control group ( $p<0.0005)$. In order to evaluate the effect of $\beta$ GP on osteogenic differentiation of ADSCs, cultures were incubated with different concentrations of $\beta$ GP in OM containing 50 $\mu \mathrm{M}$ AA and $100 \mathrm{nM}$ Dex. The ALP activity and calcium levels were significantly higher in $5 \mathrm{mM}$ and $50 \mathrm{mM} \beta \mathrm{GP}$ added to cultures compare with the control group $(p<0.05$ and $p<0.005$, respectively) (Table 1). A similar response was produced by the exposure to different doses of Dex. In comparison with controls, both $10 \mathrm{nM}$ and $1000 \mathrm{nM}$ Dex enhanced the ALP activity in the cultures ( $p<0.05$ and $p<0.0005$, respectively), but no difference was observed between OM (which contains $100 \mathrm{nM}$ Dex) and 1000 nM Dex treated cells (Table 1).

Table 1. Effect of different concentrations of $\beta$ GP and Dex on osteogenic differentiation of ADSCs in vitro

\begin{tabular}{|c|c|c|c|}
\hline & & $\begin{array}{c}\text { ALP activity } \\
\text { (p-nitrophenol } \mathrm{nmol} / \mu \mathrm{g} \text { protein) }\end{array}$ & $\begin{array}{c}\mathrm{Ca}^{2+} \text { levels } \\
(\mu \mathrm{g} / \mathrm{ml})\end{array}$ \\
\hline \multirow{2}{*}{\multicolumn{2}{|c|}{$\begin{array}{l}\text { Control (basal medium) } \\
\mathrm{OM}(10 \mathrm{mM} \beta \mathrm{GP}+100 \mathrm{nM} \text { Dex })\end{array}$}} & $27.18 \pm 5.88$ & $63.5 \pm 5.1$ \\
\hline & & $100.99 \pm 8.13^{\mathrm{a}, \mathrm{c}, \mathrm{e}}$ & $93.2 \pm 2.0^{\mathrm{a}, \mathrm{c}}$ \\
\hline & $\begin{array}{l}5 \mathrm{mM} \\
50 \mathrm{mM}\end{array}$ & $\begin{array}{c}60.96 \pm 9.18^{\mathrm{b}} \\
112.06 \pm 6.76^{\mathrm{a}, \mathrm{d}}\end{array}$ & $\begin{array}{l}76.1 \pm 3.9^{\mathrm{b}} \\
98.4 \pm 1.4^{\mathrm{a}, \mathrm{c}}\end{array}$ \\
\hline Dex & $\begin{array}{l}10 \mathrm{nM} \\
1000 \mathrm{nM}\end{array}$ & $\begin{array}{c}68.19 \pm 4.54^{\mathrm{b}} \\
129.04 \pm 20.07^{\mathrm{a}, \mathrm{e}}\end{array}$ & $\begin{array}{l}83.5 \pm 3.5^{\mathrm{b}} \\
96.9 \pm 2.6^{\mathrm{a}, \mathrm{e}}\end{array}$ \\
\hline
\end{tabular}

$\beta \mathrm{GP}$ and Dex showed dose dependent effect on ALP activity and calcium deposition. Values represent the mean \pm SEM, $n=5$. ${ }^{\mathrm{a}} p<0.0005$ and ${ }^{\mathrm{b}} p<0.05$ vs. control; ${ }^{\mathrm{c}} p<0.05$ and ${ }^{\mathrm{d}} p<0.005$ vs. $5 \mathrm{mM} \beta \mathrm{GP} ;{ }^{\mathrm{e}} p<0.05$ vs. $10 \mathrm{nM}$ Dex. 

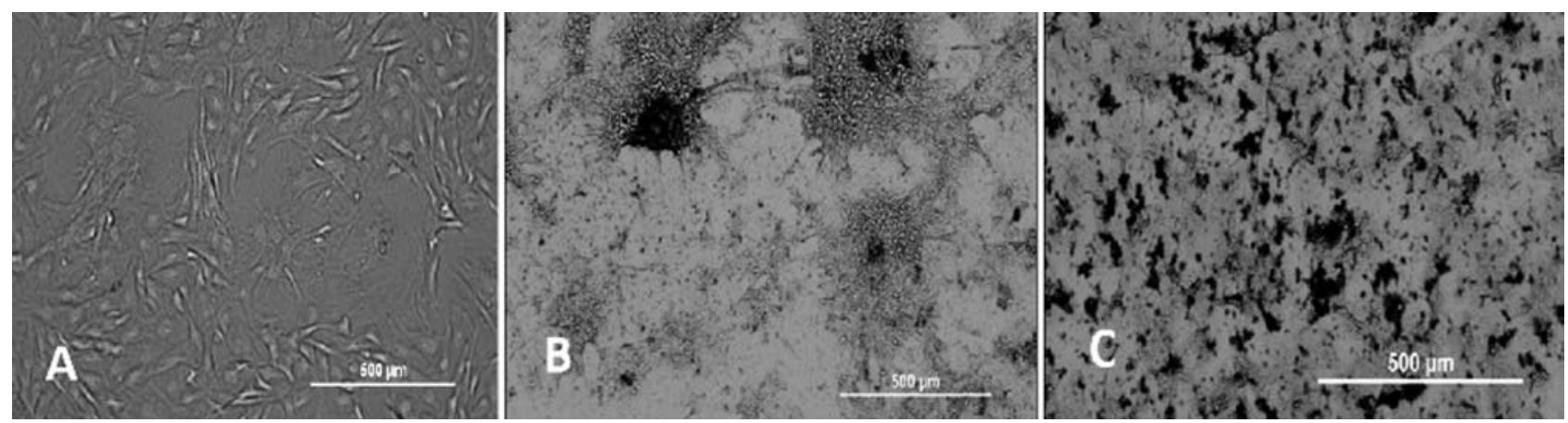

Figure 3. The effect of $E_{2}$ on osteogenic differentiation of ADSCs. A. Control cells exhibited fibroblast-like morphology and proliferated uniformly until the day 21 of the cultures. B. OM-treated cultures. Nodule formation and mineralization were clearly visualized at the end of the $3^{\text {rd }}$ week. C. Treatment of the cultures with $\mathrm{E}_{2}\left(10^{-8} \mathrm{M}\right)$ caused extensive mineralization and nodule formation compared to cells grown in OM. Bars indicate $500 \mu \mathrm{m}$.

\section{Effect of $17 \beta$-estradiol on osteogenic potential of ADSCs}

In order to test the effect of $\mathrm{E}_{2}$ on osteogenic potential of ADSCs in vitro, the cells were grown in OM supplemented with different doses of $\mathrm{E}_{2}\left(10^{-12}, 10^{-10}\right.$ and $\left.10^{-8} \mathrm{M}\right)$ for 21 days. The effect of $E_{2}$ on the formation of bone-like nodules and mineralization of the matrix was assessed by von Kossa staining of the cultures. The treatment of ADSCs with OM for 21 days caused typically mineralized nodules stained as black precipitates. In addition, the cultures grown in OM supplemented with $10^{-8} \mathrm{M} \mathrm{E}_{2}$ formed mineralized nodules widely diffused on the culture plate (Fig. 3).

All cultures treated with different doses of $\mathrm{E}_{2}$ demonstrated higher ALP activity than control cells $(p<0.0005)$. The stimulating effect of $E_{2}$ on ALP activity was dose-dependent whereas the highest ALP activity was detected in the cultures with $\mathrm{E}_{2}$ supplement at concentration of $10^{-8} \mathrm{M}$. Moreover, a significant difference was observed between the $\mathrm{OM}$ (without $\mathrm{E}_{2}$ ) and $\mathrm{OM}$ with $\mathrm{E}_{2}$ concentrations of $10^{-10}$ and $10^{-8} \mathrm{M}$ indicating a further stimulatory effect of $\mathrm{E}_{2}$ on osteogenesis in vitro ( $p<0.005$, Fig. 4$)$.

Similarly, ADSCs grown in OM supplemented with different doses of $E_{2}$ displayed higher levels of calcium compare with control cells $(p<0.0005)$, but no difference was detected between the $\mathrm{OM}$ (without $\mathrm{E}_{2}$ ) and $\mathrm{OM}$ with $\mathrm{E}_{2}$ concentrations of $10^{-12}$ and $10^{-10} \mathrm{M}$. However, the treatment of the cells with $10^{-8} \mathrm{M} \mathrm{E}_{2}$ caused a significant increase in calcium content compare with OM group ( $p<0.005$, Fig. 5 ).

\section{Discussion}

The present study revealed that $\mathrm{E}_{2}$ may have a stimulatory effect on osteoblastic differentiation of ADSCs isolated from rats. Supplementation of $E_{2}$ significantly enhanced ALP activity, calcium levels and mineral deposition in the cultures.

As indicated in earlier studies, steroid hormones strongly contribute in bone metabolism and have modulatory effects in many cell types including BMSCs. Stem cells require glucocorticoids in the culture medium for osteogenic, chondrogenic and adipogenic differentiation (Jaiswal et al. 1997; Zuk et al. 2002; Alhadlaq et al. 2004; Ray et al. 2008). Glucocorticoids, including Dex, promote osteogenic differentiation and induce the formation of bone-like nodules in embryonic and adult stem cells cultures. Although Dex is a potent inducer of osteogenic differentiation, it also posseses a dose-related inhibitory effect on proliferation of bone marrow cells in vitro

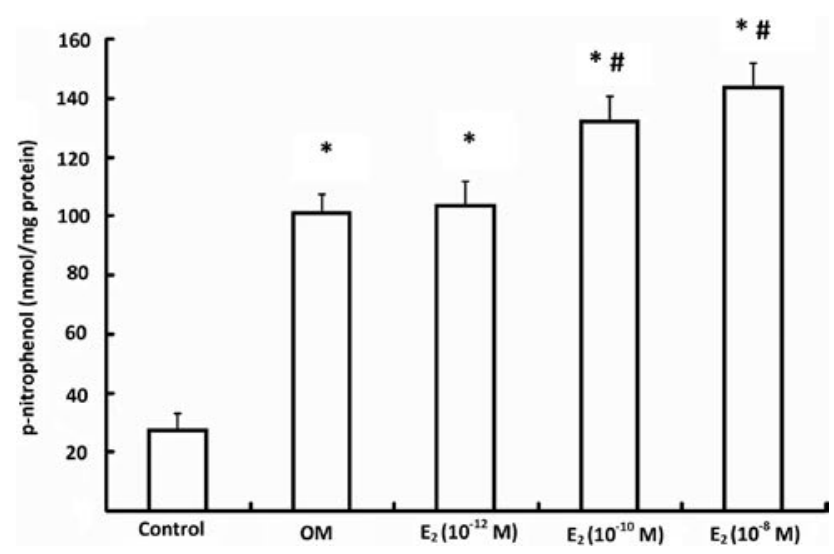

Figure 4. ALP activities in ADSCs cultures. ALP activity was significantly higher in all the groups than in the control. The addition of $\mathrm{E}_{2}$ (both $10^{-10} \mathrm{M}$ and $10^{-8} \mathrm{M}$ ) into OM significantly increased the enzyme activity compared to OM-treated group. Values represent the mean \pm SEM, $n=5 .{ }^{*} p<0.0005 v s$. control and $\# p<0.05 v s$. OM-treated group. 


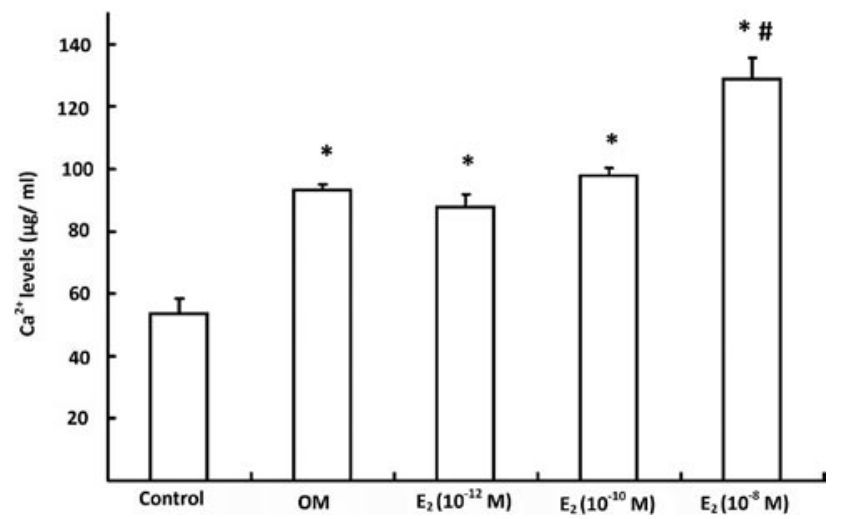

Figure 5. The amount of calcium deposition in cell lysates of ADSCs cultures. All groups showed higher levels of calcium than in the control. The highest calcium level was found in the $\mathrm{OM}$ supplemented with $\mathrm{E}_{2}\left(10^{-8} \mathrm{M}\right)$ group. Values represent the mean \pm SEM, $n=5 .{ }^{*} p<0.0005$ vs. control; $\# p<0.05$ vs. OM and OM with $\mathrm{E}_{2}$ (both $10^{-12} \mathrm{M}$ and $10^{-10} \mathrm{M}$ ) treated groups.

(Walsh et al. 2001). In an effort to identify the optimal culture conditions for osteogenic differentiation, we cultured these cells in OM with three different doses of Dex (10 nM, $100 \mathrm{nM}$ and $1 \mu \mathrm{M}$ ) for 21 days. Consistent with the previous studies, we observed a dose-dependent effect of Dex on ALP activities and calcium levels compared with control. The highest ALP activity and calcium level were measured in the cultures treated with $1000 \mathrm{nM}$ Dex, however, this dose typically resulted in detachment of the cells from the surface of the plate during the culture period. We also investigated the effect of of $\beta$ GP on osteogenic potential of ADSCs by adding different doses $(5,10$ and $50 \mathrm{mM})$ of $\beta \mathrm{GP}$ into OM. Although there was a significant increase in ALP activity and calcium levels with all doses of $\beta$ GP compared with control, no difference was observed between the cultures exposed to 10 and $50 \mathrm{mM}$ $\beta$ GP. In the present study, both histological and biochemical results clearly demonstrated that the addition of osteogenic supplements including $100 \mathrm{nM}$ Dex, $10 \mathrm{mM} \beta \mathrm{GP}$ and $50 \mu \mathrm{M}$ AA is sufficient for a rapid osteogenesis in ADSCs cultures.

Estrogens possess an important role in the regulation of osteogenesis both in human and animals. Experimental studies have demonstrated that $\mathrm{E}_{2}$ not only inhibits bone resorption but also stimulates bone formation (Chow et. 1992). $\mathrm{E}_{2}$ exerts its physiological effects on target tissues via intracellular estrogen receptors ER- $\alpha$ and ER- $\beta$, which are discovered on many cell types. Bodine et al. (1998) reported increased levels of estrogen receptor during osteoblast differentiation in primary cultures of rat calvarial osteoblasts. More recently, it has been suggested that $\mathrm{E}_{2}$ may also effectively enhance the differentiation capacity of both embryonic stem cells and BMSCs into ostoeblasts in vitro (Qu et al. 1998; Hong et al. 2006; Tielens et al. 2008).
In osteogenesis studies using osteoblast or stem cell cultures, ALP measurement is considered as an early marker of osteogenic differentiation whereas calcium deposition in the cultures usually reflect the endpoint of osteogenesis in vitro. Enhanced ALP expression in response to $E_{2}$ by osteoblasts and stem cells was demonstrated in some recent studies $(\mathrm{Qu}$ et al. 1998; Holzer et al. 2002; Tielens et al. 2008; Hoemann et al. 2009). Furthermore, $E_{2}$ probably acts not only to control the ALP activity of cells expressing the enzyme, but also the proliferation rate of ALP-expressing cells in the marrow stromal cell population (Holzer et al. 2002). In contrast, no stimulatory effect on ALP expression and proliferation of human marrow stromal cells was described by other investigators (Kim and Cheng 1994).

In the present study, we cultured rat ADSCs in OM supplemented with different doses of $\mathrm{E}_{2}$ to investigate whether $\mathrm{E}_{2}$ has a stimulatory effect on osteogenic differentiation potential. Our results showed a dose-dependent enhancement in ALP activities in the cultures treated with $\mathrm{E}_{2}$, whereas the calcium level was significantly elevated only at concentration of $10^{-8} \mathrm{M} \mathrm{E}_{2}$ compared with the cells treated with only OM. Furthermore, as confirmed by histological evaluation of the cultures with von Kossa staining, $\mathrm{E}_{2}$-supplemented cultures demonstrated more extensive nodule formation and calcium deposition compare with the cells treated with OM.

Consistent with our findings, Hong et al. (2007) have reported that estrogen may have a modulatory role on the osteogenic and adipogenic differentiation of human ADSCs isolated from a healthy female donor. Similarly, they observed an increase in ALP activities, calcium levels and matrix calcification in the cultures treated with $\mathrm{E}_{2}$ at concentrations of $10^{-9}$ and $10^{-8} \mathrm{M}$. In a recent paper, the same researchers indicated that $\mathrm{E}_{2}$ and Dex interactively stimulate the proliferation and osteogenic differentiation of human BMSCs isolated from both male and female donors, but optimal concentration of $\mathrm{E}_{2}$ may differ with the gender (Hong et al. 2009). In another study, Aksu et al. (2008) have reported the effects of some variables such as gender, fat depot and optimal duration on osteogenic potential of human ADSCs. According to their findings, whereas male ADSCs isolated from superficial adipose layer have greater osteogenic capacity than deep layer cells, no significant difference was observed between the cultures isolated from female donors. In contrast to our and previous results, $\mathrm{Ng}$ et al. (2009) found that both donor reproductive status (pregnancy, premenopause and postmenopause) and in vitro $\mathrm{E}_{2}$ treatment have no significant effect on proliferation rate of human ADSCs. Overall, these conflicting findings may reflect the fact that proliferation rate and differentiation potential of stem cells including ADSCs can be influenced by several factors, such as donor age, gender, cell isolation and culture techniques, tissue sources. Stem cells themselves may also produce 
autocrine and paracrine factors during proliferation and differentiation depending on different culture conditions. In addition, regulatory effects of $\mathrm{E}_{2}$ on cell proliferation and osteoblastic differentiation could be mediated by not only its specific receptors but also some osteogenic growth factors, including BMP-6 and TGF- $\beta 1$ (Qu et al. 1998; Plant and Tobias 2002).

In summary, our present results suggest that in vitro osteogenic potential of ADSCs can be influenced by $\mathrm{E}_{2}$ treatment in a dose-dependent manner. However, further in vitro and in vivo studies are required to improve the effectiveness of ADSCs in tissue engineering and regenerative medicine.

\section{References}

Aksu A. E., Rubin J. P., Dudas J. R., Marra K. G. (2008): Role of gender and anatomical region on induction of osteogenic differentiation of human adipose-derived stem cells. Ann. Plast. Surg. 60, 306-322 doi:10.1097/SAP.0b013e3180621ff0

Alhadlaq A., Mao J. J. (2004): Mesenchymal stem cells: Isolation and therapeutics. Stem Cells Dev. 13, 436-448 doi:10.1089/scd.2004.13.436

Bodine P. V., Henderson R. A., Green J., Aronow M., Owen T., Stein G. S., Lian J. B., Komm B. S. (1998): Estrogen receptor-alpha is developmentally regulated during osteoblast differentiation and contributes to selective responsiveness of gene expression. Endocrinology 139, 2048-2057 doi:10.1210/en.139.4.2048

Bradford M. M. (1976): A rapid and sensitive method for the quantitation of microgram quantities of protein utilizing the principle of protein-dye binding. Anal. Biochem. 72, 248-254 doi:10.1016/0003-2697(76)90527-3

Caplan A. I. (2007): Adult mesenchymal stem cells for tissue engineering versus regenerative medicine. J. Cell. Physiol. 213, 341-347 doi: $10.1002 /$ jcp. 21200

Chow J., Tobias J. H., Colston K. W., Chambers T. J. (1992): Estrogen maintains trabecular bone volume in rats not only by suppression of bone resorption but also by stimulation of bone formation. J. Clin. Invest. 89, 74-78 doi:10.1172/JCI115588

De Ugarte D. A., Morizono K., Elbarbary A., Alfonso Z., Zuk P. A., Zhu M., Dragoo J. L., Ashjian P., Thomas B., Benhaim P., Chen I., Fraser J., Hedrick M. H. (2003): Comparison of multi-lineage cells from human adipose tissue and bone marrow. Cells Tissues Organs 174, 101-109 doi: $10.1159 / 000071150$

Han H. J., Heo J. S., Lee Y. J. (2006): Estradiol-17beta stimulates proliferation of mouse embryonic stem cells: involvement of MAPKs and CDKs as well as protooncogenes. Am. Physiol. Cell Physiol. 290, 1067-1075 doi:10.1152/ajpcell.00222.2005

Hoemann C. D., El-Gabalawy H., McKee M. D. (2009): In vitro osteogenesis assays: Influence of the primary cell source on alkaline phosphatase activity and mineralization. Pathol. Biol. $\mathbf{5 7}, 318-323$ doi:10.1016/j.patbio.2008.06.004

Holzer G., Einhorn T. A., Majeska R. J. (2002): Estrogen regulation of growth and alkaline phosphatase expression by cultured human bone marrow stromal cells. J. Orthop. Res. 20, 281-288

Hong S. H., Nah H. Y., Lee Y. J., Lee J. W., Park J. H., Kim S. J., Lee J. B., Yoon H. S., Kim C. H. (2004): Expression of estrogen receptor-alpha and -beta, glucocorticoid receptor, and progesterone receptor genes in human embryonic stem cells and embryoid bodies. Mol. Cells 18, 320-325

Hong L., Colpan A., Peptan I. A. (2006): Modulations of 17-beta estradiol on osteogenic and adipogenic differentiations of human mesenchymal stem cells. Tissue Eng. 12, 2747-2753 doi:10.1089/ten.2006.12.2747

Hong L., Colpan A., Peptan I. A., Daw J., George A., Evans C. A. (2007): 17-Beta estradiol enhances osteogenic and adipogenic differentiation of human adipose-derived stromal cells. Tissue Eng. 13, 1197-1203 doi:10.1089/ten.2006.0317

Hong L., Sultana H., Paulius K., Zhang G. (2009): Steroid regulation of proliferation and osteogenic differentiation of bone marrow stromal cells: a gender difference. J. Steroid Biochem. Mol. Biol. 114, 180-185 doi:10.1016/j.jsbmb.2009.02.001

Huang J. I., Beanes S. R., Zhu M., Lorenz H. P., Hedrick M. H., Benhaim P. (2002): Rat extramedullary adipose tissue as a source of osteochondrogenic progenitor cells. Plast. Reconstr. Surg. 109, 1033-1041 doi:10.1097/00006534-200203000-00037

Jäger M., Feser T., Denck H., Krauspe R. (2005): Proliferation and osteogenic differentiation of mesenchymal stem cells cultured onto three different polymers in vitro. Ann. Biomed. Eng. 33, 1319-1332 doi:10.1007/s10439-005-5889-2

Jaiswal N., Haynesworth S. E., Caplan A. I., Bruder S. P. (1997): Osteogenic differentiation of purified, culture-expanded human mesenchymal stem cells in vitro. J. Cell. Biochem. 64, 295-312

doi:10.1002/(SICI) 1097-4644(199702)64:2<295::AID-JCB12>3.0.CO;2-I

Kim G. S., Cheng S. L. (1994): Absence of a direct anabolic effect of 17beta-estradiol on normal human bone marrow stromal cells. Korean J. Intern. Med. 9, 14-19

Krampera M., Pizzolo G., Aprili G., Franchini M. (2006): Mesenchymal stem cells for bone, cartilage, tendon and skeletal muscle repair. Bone 39, 678-683 doi:10.1016/j.bone.2006.04.020

Ng L. W., Yip S. K., Wong H. K., Yam G. H., Liu Y. M., Lui W. T., Wang C. C., Choy K. W. (2009): Adipose-derived stem cells from pregnant women show higher proliferation rate unrelated to estrogen. Hum. Reprod. 24, 1164-1170 doi:10.1093/humrep/dep001

Peng L., Jia Z., Yin X., Zhang X., Liu Y., Chen P. (2008): Comparative analysis of mesenchymal stem cells from bone marrow, cartilage, and adipose tissue. Stem Cells Dev. 17, 761-773 doi:10.1089/scd.2007.0217 
Plant A., Tobias J. H. (2002): Increased bone morphogenetic protein- 6 expression in mouse long bones after estrogen administration. J. Bone Miner. Res. 17, 782-790 doi:10.1359/jbmr.2002.17.5.782

Qu Q., Perälä-Heape M., Kapanen A., Dahllund J., Salo J., Väänänen H. K., Härkönen P. (1998): Estrogen enhances differentiation of osteoblasts in mouse bone marrow culture. Bone 22, 201-209 doi:10.1016/S8756-3282(97)00276-7

Ray R., Novotny N. M., Crisostomo P. R., Lahm T., Abarbanell A., Meldrum D. R. (2008): Sex steroids and stem cell function. Mol. Med. 14, 493-501 doi:10.2119/2008-00004.Ray

Romanov Y. A., Darevskaya A. N., Merzlikina N. V., Buravkova L. B. (2005): Mesenchymal stem cells from human bone marrow and adipose tissue: isolation, characterization, and differentiation potentialities. Bull. Exp. Biol. Med. 140, 138-143 doi:10.1007/s10517-005-0430-Z

Shirasawa S., Sekiya I., Sakaguchi Y., Yagishita K., Ichinose S., Muneta T. (2006): In vitro chondrogenesis of human synovium-derived mesenchymal stem cells: optimal condition and comparison with bone marrow-derived cells. J. Cell. Biochem. 97, 84-97 doi:10.1002/jcb.20546

Tholpady S. S., Katz A. J., Ogle R. C. (2003): Mesenchymal stem cells from rat visceral fat exhibit multipotential differentiation in vitro. Anat. Rec. A. Discov. Mol. Cell. Evol. Biol. 272, 398-402

doi:10.1002/ar.a.10039
Tielens S., Wymeersch F., Declercq H., Cornelissen M. (2008): Effect of 17 beta-estradiol on the in vitro differentiation of murine embryonic stem cells into the osteogenic lineage. In Vitro Cell. Dev. Biol. Anim. 44, 368-378 doi:10.1007/s11626-008-9126-9

Walsh S., Jordan G. R., Jefferiss C., Stewart K., Beresford J. N. (2001): High concentrations of dexamethasone suppress the proliferation but not the differentiation or further maturation of human osteoblast precursors in vitro: relevance to glucocorticoid-induced osteoporosis. Rheumatology 40, 74-83 doi:10.1093/rheumatology/40.1.74

Zhou S., Zilberman Y., Wassermann K., Bain S. D., Sadovsky Y., Gazit D. (2001): Estrogen modulates estrogen receptor alpha and beta expression, osteogenic activity, and apoptosis in mesenchymal stem cells (MSCs) of osteoporotic mice. J. Cell. Biochem. Suppl. 36, 144-155 doi:10.1002/jcb.1096

Zhu Y., Liu T., Song K., Fan X., Ma X., Cui Z. (2008): Adipose-derived stem cell: a better stem cell than BMSC. Cell Biochem. Funct. 26, 664-675 doi:10.1002/cbf. 1488

Zuk P. A., Zhu M., Ashjian P., De Ugarte D. A., Huang J. I., Mizuno H., Alfonso Z. C., Fraser J. K., Benhaim P., Hedrick M. H. (2002): Human adipose tissue is a source of multipotent stem cells. Mol. Biol. Cell. 13, 4279-4295 doi:10.1091/mbc.E02-02-0105

Received: May 7, 2010

Final version accepted: November 11, 2010 